Rev. Téc. Ing. Univ. Zulia. Vol. 42, No. 2, 2019, 67-75

\title{
Support materials of fixed biofilm based on solid plastic wastes for domestic wastewater treatment
}

\author{
K. Espinoza ${ }^{1}$, C. Fernández ${ }^{1}$, J. Pérez ${ }^{1}$ (D) D. Benalcazar ${ }^{1}$, D. Romero $^{1}$, B. Lapo $^{1 *} \mathbb{D}$ \\ ${ }^{1}$ Laboratorio de Investigaciones, Grupo BIOeng, Carrera de Ingeniería Química, UACQS, Universidad Técnica de Machala, \\ Machala, 070151, Ecuador \\ *Autor de Contacto: blapo@utmachala.edu.ec \\ https://doi.org/10.22209/rt.v42n2a03 \\ Recepción: 03/10/2017 | Aceptación: 20/02/2019| Publicación: 01/05/2019
}

\begin{abstract}
The application of three kinds of solid plastic wastes as support materials in aerobic fixed bed biofilm reactors to treat domestic wastewater were assessed. The plastic wastes evaluated were: low density polyethylene (LDPE), polyethylene terephthalate (PET) and high-density polyethylene (HDPE). Three reactors of $12 \mathrm{~L}$ were assembled and operated for 182 days divided into three phases of 90 days each, where the volumetric organic loading was varied between 1.6 to $3.5 \mathrm{~kg}$ COD $\mathrm{m}^{-3} \mathrm{dia}^{-1}$. To obtain better surface conditions, low density polyethylene material was thermally modified (m-LDPE). Scanning electron microscopy was used to observe the plastic surface before and after the biomass adhesion. In addition, chemical oxygen demand and attached volatile suspended solids were monitored to know the organic matter removal and the biomass formation over the materials respectively. COD removals over $80 \%$ was achieved for m-LDPE and PET, meanwhile HDPE shows lower COD efficiencies. The best cell adhesion was achieved to the m-LDPE, mainly due to the high roughness acquired during the thermal modification applied.
\end{abstract}

Keywords: Biofilm; Plastic wastes; Wastewater treatment.

\section{Desechos sólidos plásticos como materiales de soporte de biopelícula fija aplicados al tratamiento de aguas residuales}

\section{Resumen}

Se determinó la posibilidad de aplicación de residuos sólidos plásticos en el tratamiento de aguas residuales. Se evaluó el uso de tres tipos de residuos sólidos plásticos: polietileno de baja densidad (LDPE), polietileno tereftalato (PET) y polietileno de alta densidad (HDPE) como materiales de soporte en reactores de biopelícula fija para el tratamiento de aguas residuales domésticas, a escala de laboratorio. Fueron montados tres reactores de $12 \mathrm{~L}$, y se operaron durante 182 días divididos en tres fases de 90 días, donde la carga orgánica volumétrica se varió entre 1.6 y $3.5 \mathrm{~kg} \mathrm{DQO} \mathrm{m}^{-3}$ dia-1. Para obtener mejores condiciones de superficie para la adherencia bacteriana, el polietileno de baja densidad fue modificado térmicamente (m-LDPE). Se utilizó microscopía electrónica de barrido para evaluar la morfología y formación de biomasa en las superficies plásticas antes y después de la adhesión de la biomasa. Fue monitoreada la demanda química de oxígeno y sólidos suspendidos volátiles adheridos en los materiales de soporte, para conocer la eliminación de materia orgánica y la formación de biomasa respectivamente, obteniendo eficiencias superiores al 80\% de remoción de DQO para los materiales m-LDPE y PET, mientras que el HDPE presentó menores eficiencias. La mejor adherencia de biomasa y eficiencias de remoción fue encontrada en el m-LDPE, debido principalmente por la mayor rugosidad obtenida durante la modificación del material.

Palabras clave: Tratamiento de aguas residuales; Biopelícula; Residuos plásticos. 


\section{Introduction}

Wastes from solid plastics are causing global and local connotation due to its large amounts delivered to the environment and low bio-degradability. Ecuador, is one of the biggest banana producer countries [1]; in this country high quantities of plastic bags or low-density polyethylene (LDPE) are discarded, since these plastics serve to protect banana fruits during its growing. For example, weekly for every 145 hectares, the agri-exporter company Frutinter S.A., consumes 6000 plastic bags for the protection of banana fruit, which are mainly LDPE. Besides, plastic bottles such as polyethylene terephthalate (PET) and high-density polyethylene (HDPE) are also the high waste plastics discarded in urbanized areas.

On the other hand, most of the populations in nondeveloped countries do not have efficient and sustainable wastewater treatment systems, mainly because to the lack of low-cost technologies. The developing of cheap and easy-to-operate wastewater treatment methods are crucial in order to surpass the low economies issues and maintain the sanitation. Among the most used methods to wastewater treatment are biological processes, as they are economically viable compared to other processes such as advanced oxidation or precipitation [2-6]i.e. vehicle operating costs and speeds are also allowed to vary over time. The multiple period models presented here allow some of the optimized system characteristics (e.g. route structure. Biofilm-based reactors are biological methods increasingly used for biological processes because they give an efficient solution [7], these methods necessarily need support media to biofilm growth. One of the most influential factors for the effectiveness in this type of systems are the support materials used, which must provide the necessary characteristics to produce and accumulate large quantities of bacteria to digest the organic load supplied quickly. To this end, various support media have been tested and developed on an industrial scale; so there are commercial manufacturers such as: Veolia Inc., Headworks BIO, AqWise, Siemens Water Technologies Corp, among others.

The development of biofilm is influenced by several processes, including the adsorption and desorption of microorganisms on the solid surface, biofilm growth and detachment [8]. At steady state, the balance between biofilm growth and detachment determines the physical structure of the biofilm [9], and hence their settling and fluidization characteristics. For efficient operation of the reactors, high concentrations of biomass present in a stable form are essential [10]. It is possible that high density discarded plastics such as PET or HDPE, and/or LDPE may be used as support for biofilm formation, as long as these inert materials have a high surface area, roughness and microbial affinity. In the case of LDPE, it does not have the features need to be immersed in the water, however, due to its thermoplastic behavior, it could be thermally modified in order to get more density and roughness need to immersion into the water and cell adhesion. The maximum cell adhesion is directly associated with the surface roughness and surface tension in polymeric biomaterials [11]. Besides, most of the studies indicate that it is necessary to maintain the control and monitoring the operating parameters such as hydraulic and organic loading, since depending on them, a suspended biomass control will have to be carried out [12].

The present projectseeks to know the application of discarded plastics LDPE, PET and HDPE as biofilm support in aerobic biological reactors, as these materials are the most common plastic wastes found in the south of Ecuador, furthermore, to apply the LDPE, it was thermally modified to increase the density and enhance the surface roughness. According to this, this research is looking for study of the optimum operational parameters to treat domestic wastewater using these wastes.

\section{Experimental Section}

\section{Choice of Support Materials}

To choose the support materials, a previous inquiry was carried out in the city of Machala-Ecuador, which consisted in visiting the recycling centers four times during one month, in order to define what kind of plastics are the most common. One collection of the recycled materials was done after to the survey data analysis. In addition, it was verified that these support materials match different criteria as high density, high surface area, and low percentage of occupied volume by the material in the reactor. The support media selected for the study were as follows: PET (bottles of carbonated and non-carbonated beverages for human consumption), HDPE (bottles of disinfectants) and LDPE (plastic bags for ripening bananas discarded).

\section{Modification of LDPE}

In the case of LDPE, it was necessary to increase the density, as the LDPE cannot be immersed in the water. It could be thermally modified to get a heavier material as well as to improve the surface characteristics. The treatment favor the attachment and remaining of biofilm on the materials $[10,13,14]$. The thermal treatment consisted in maintaining the LDPE to exactly $105^{\circ} \mathrm{C}$ for 15 minutes in a stove. The new material is this paper is named m-LDPE.

The Table 1 shows the physical characteristics of the support means used whose data was taken from the bibliography. 
Table 1. Physical characteristics of the carrier materials

\begin{tabular}{ccccc}
\hline Feature & units & PET & HDPE & LDPE \\
\hline $\begin{array}{c}\text { Superficial area } \\
\text { Tensile strength }\end{array}$ & $\mathrm{m}^{2} \mathrm{~m}^{-3,}$ & 1.43 & 0.26 & - \\
$\begin{array}{c}\text { Volume occupied by } \\
\text { the material in the } \\
\text { reactor }\end{array}$ & $\mathrm{MPa}$ & 55 & 32 & 10 \\
Density & $\%$ & 60 & 60 & 60 \\
\hline
\end{tabular}

\section{Reactors and Wastewater}

Three reactors made on acrylic material of total capacity of $12 \mathrm{~L}$ were used. The assembly of the reactors could be seen in the figure 1 :

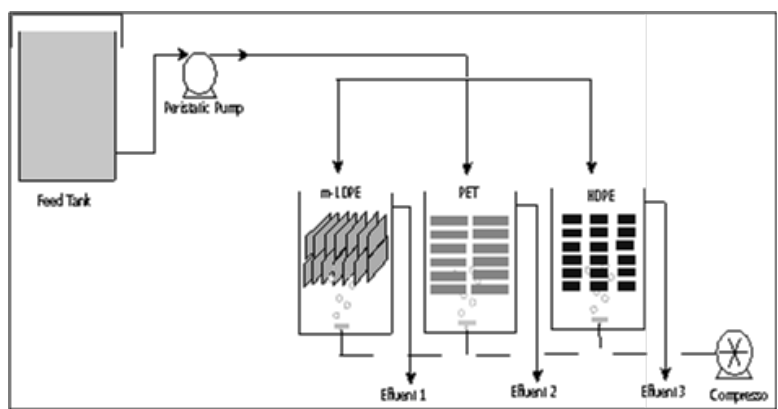

Figure 1. Experimental diagram

Real domestic wastewater from MachalaEcuador was used, this was collected from a gutter which conduce the urban wastewater to the sea. Prior to feed the reactors, this was clarified by 24 hours of gravimetric sedimentation in a $200 \mathrm{~L}$ volume tank. The water used had the following physical chemical characteristics detailed in Table 2.

Table 2. Characteristics of domestic wastewater

\begin{tabular}{|c|c|c|c|}
\hline characteristics & units & value & $\begin{array}{l}\text { Standard } \\
\text { deviation }\end{array}$ \\
\hline Temperature & ${ }^{\circ} \mathrm{C}$ & 23.2 & - \\
\hline $\mathrm{pH}$ & - & 7.11 & - \\
\hline COD & $\mathrm{mg} \mathrm{L}^{-1}$ & 627 & 100.97 \\
\hline $\mathrm{DBO}_{5}$ & $\mathrm{mg} \mathrm{L}^{-1}$ & 237 & 47.23 \\
\hline SSV & $\mathrm{mg} \mathrm{L}^{-1}$ & 314.4 & 125.26 \\
\hline NTK & $\mathrm{mg} \mathrm{L}^{-1}$ & 31 & - \\
\hline $\mathrm{N}-\mathrm{NH}_{4}+:$ & $\mathrm{mg} \mathrm{L}^{-1}$ & 3.01 & - \\
\hline $\mathrm{P}$ & $\mathrm{mg} \mathrm{L}^{-1}$ & 6.66 & - \\
\hline
\end{tabular}

\section{Operating Conditions in the System}

The reactors were operated in continuous. The duration of the experimental was carried out in three phases of 60 days, where was varied the organic volumetric load (LV) in 1.6, 2.4 and $3.5 \mathrm{~kg} \mathrm{COD} \mathrm{m}^{3} \mathrm{~d}^{-1}$ in phase 1, phase 2 and phase 3 respectively; detailed in Table 3 . The response parameters were: COD in the effluent, SSV in the mixed liquor, organic matter removal efficiency, and growth of biomass in the support media. The $\mathrm{pH}$ and temperature throughout the process were constant. The Table 3 shows the operational parameters used.

Table 3. Operating parameters in the system

\begin{tabular}{ccccc}
\hline & UNITS & PHASE 1 & PHASE 2 & PHASE 3 \\
\hline Duration & Day & 60 & 60 & 60 \\
$\mathrm{~L}_{\mathrm{v}}$ & $\mathrm{kg} \mathrm{COD} \mathrm{m}^{-3} \mathrm{~d}^{-1}$ & 1.6 & 2.4 & 3.5 \\
HRT & $\mathrm{h}$ & $9.6 \pm 0.23$ & $6.8 \pm 0.36$ & $5.0 \pm 0.26$ \\
Flow & $\mathrm{L} \mathrm{h}^{-1}$ & $1.2 \pm 0.03$ & $1.8 \pm 0.09$ & $2.4 \pm 0.13$ \\
\hline
\end{tabular}

Before the reactors were started, it took around 30 days to achieve good bacterial growth in the support media which was operated with a volumetric load of 1.6 $\mathrm{kg} \operatorname{COD~m^{-3}} \mathrm{d}^{-1}$.

\section{Analytical Methods}

Measurements of the parameters listed in Table 4 were done in the feeding wastewater, meanwhile, CODs, $\mathrm{pH}$ and temperature were monitored at the outlet of the reactors. Besides, biomass detachment was monitored weekly by the analysis of SSV (mg SSV L-1) in the mixed liquor, according to [15]. Analyzes of $\mathrm{BOD}_{5}$, nitrogen and total phosphorus were done at the beginning and intermediate periods of the study to corroborate the COD:BOD and COD:N:P ratios. 
Table 4. Parameters and measurement techniques

\begin{tabular}{ccc}
\hline Parameter & Units & Method \\
\hline Temperature & ${ }^{\circ} \mathrm{C}$ & Thermometric \\
$\mathrm{pH}$ & - & $4500-\mathrm{H} / \mathrm{PH} /[16]$ \\
$\mathrm{CODs}$ & $\mathrm{mgL}-1$ & $5220 / \mathrm{COD} /[16]$ \\
$\mathrm{DBO5}$ & $\mathrm{mgL}-1$ & $5210 / \mathrm{BOD} 5 /[16]$ \\
$\mathrm{SSV}$ & $\mathrm{mgL}-1$ & {$[17]$} \\
$\mathrm{N}$ & $\mathrm{mgL}-1$ & $5220 / \mathrm{NT} /[16]$ \\
& & $4500-\mathrm{N} / \mathrm{N}-\mathrm{NH} 4 /$ \\
$\mathrm{N}-\mathrm{NH} 4+$ & $\mathrm{mgL}-1$ & {$[16,18]$} \\
& & $4500-\mathrm{P} / \mathrm{phosphorous} /$ \\
$\mathrm{P}$ & $\mathrm{mgL}-1$ & {$[16,18]$} \\
& & {$[17]$} \\
$\mathrm{SST}$ & $\mathrm{mgL}-1$ &
\end{tabular}

Material surface and biomass growth was verified by electronic scanning microscopy (SEM) with a Phenom World Pro X microscope. Prior to observations, the samples were dehydratated in a stove for 24 hours at $38^{\circ} \mathrm{C}$, fixed in the sample holder with a conductive tape and sputter with carbon, the SEM conditions were $5 \mathrm{kV}$ and $10^{-5}$ torr in a sample holder provided with charge reductor.

In the case of biomass growth on the support materials, it was measured through the SSV adhered in the materials $[15,19]$. This value was obtained using the method reported by Lapo etal. [20], with few modifications. Briefly, convenient slides of material were taken from the reactors, then the materials were washed with deionized water, ultrasonicated for $30 \mathrm{~min}$, procuring remove and transfer all the organic matter from the material to the water; after that the total mass of SSV were quantified. This value was extrapolated to all support materials and finally reported as grams of SSV by material square meter (g SSV m²).

\section{Results and Discussion}

\section{Choice of Support Materials}

After the survey done to recycler stations, it was found that, the major of wastes correspond to banana bags with $42.8 \%$, followed by PET with 29.7\%, HDPE with $21.1 \%$ and others with $6.4 \%$. The plastic bottles and the containers of drums have a low recycling percentage, these come mainly from the plastic bottles and beverage containers. Regarding to the kind and quantity of plastic wastes found in recycling stations, LDPE plastic was the major, it would be explained as the main economic activity in this region is banana exportation, consequently are delivered tons on LDPE, as this material is used along all the banana farms to protect the fruits from biocides. Regarding to the other plastic wastes, the values found could be compared with other similar recyclers in the country [21,22].

\section{Biomass Growing}

The biomass growth was measured as the total amount of SSV on the materials, moreover the material surfaces were observed by SEM.

Regarding to SSV formation on the surfaces, the Figure 2 shows the amount of SSV attached to biomass.

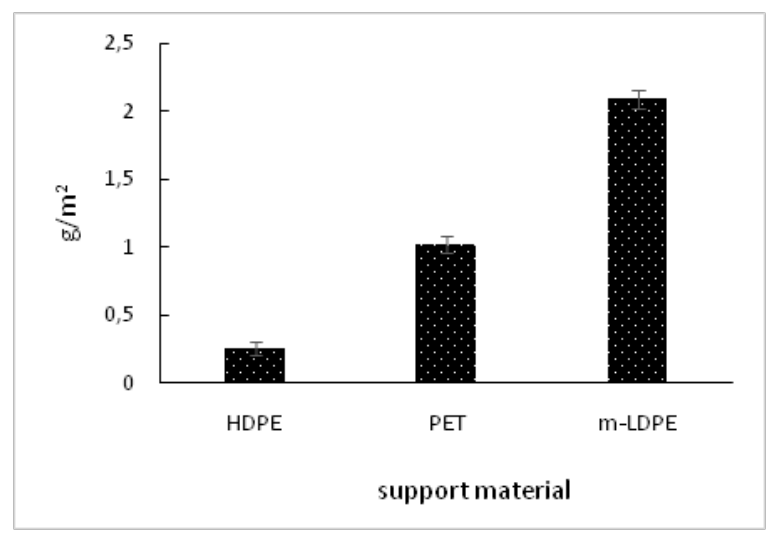

Figure 2. Biomass growth on material

In Figure 2 is possible to observe the amount of biomass formed by surface area. The material m-LDPE can accumulate around $2 \mathrm{~g}$ of SSV $\mathrm{m}^{-2}$, meanwhile PET and HDPE retain on the surface 1.02 and $0.25 \mathrm{~g} \mathrm{~m}^{-2}$ respectively. It is to say that m-LDPE showed around twice adhesion than PET, and eight times more than HDPE.

SEM images confirms the found in attached SSV evaluations, which is showed in Figure 3. The microphotographs allow to observe the morphology of the materials. Figure 3(a) shows the surface of LDPE without modification; it is observed a low roughness surface, compared with the LDPE thermally modified in Figure 3(b), named $\mathrm{m}$-LDPE, where it can be observed the high roughness achieved after the treatment, which favors the adhesion of bacteria; besides it is noticed that the holes obtained is around $1 \mu \mathrm{m}$.

The Figure 3 shows SEM microphotographs, where biomass adherence is observed in each support material, before and after experimentation. 

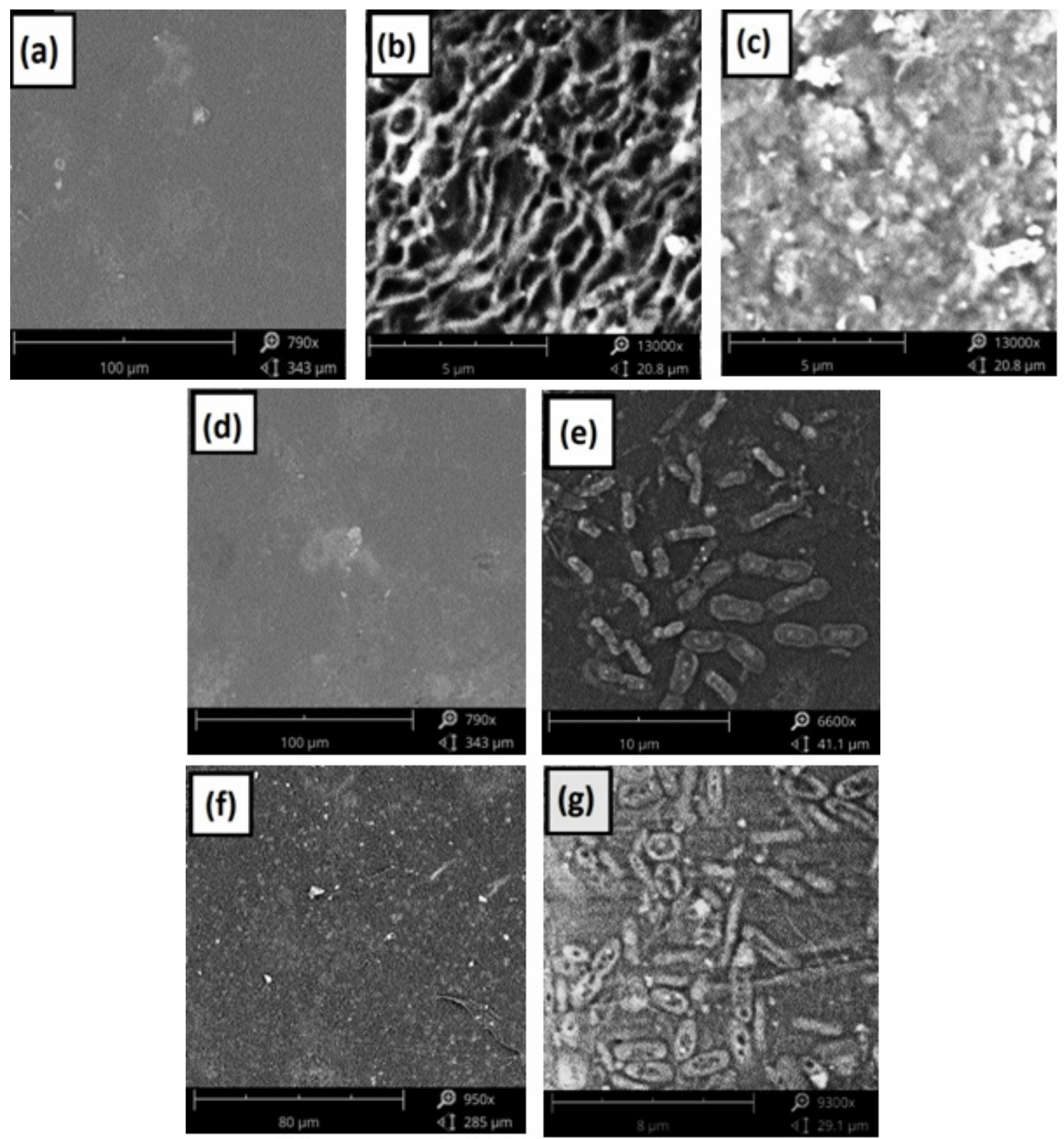

Figure 3. Surface observations by SEM: a) LDPE no modified b) m-LPDE (without biofilm), c) m-LDPE (with biofilm), d) PET (without biofilm), e) PET (with biofilm), f) HDPE (without biofilm), g) HPDE (with biofilm).

The 3(c) photo shows the biomass formed in this same support media after 30 days from the initial inoculation. In Figure 3(d) and 3(f) it is observed the materials PET and HDPE respectively, before the biomass attachment, in the same way $3(\mathrm{e})$ and $3(\mathrm{~g})$ show the attached biomass in PET and HDPE respectively, where it is showed low amounts of adhered biomass.

On the other hand, the concentration of SSV formed in the mixed liquor during the 3 experimentation phases is showed in Figure 4. 


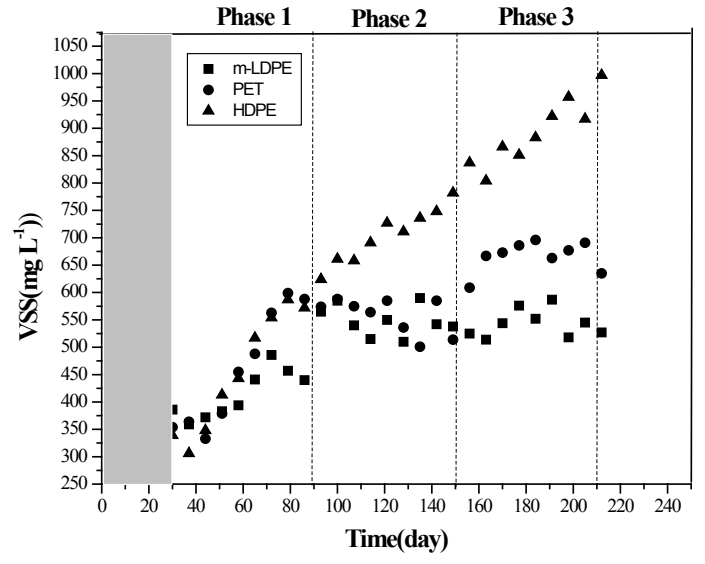

Figure 4. Concentration of biomass in mixed liquor at each stage of experimentation.

According to the Figure 4, during the phase 1, the SSV concentration in $\mathrm{m}$-LDPE, PET and HDPE reactors show a constant increment from around $300 \mathrm{mg} \mathrm{L}^{-1}$ to 590 $\mathrm{mg} \mathrm{L}^{-1}$, then in phase 2 it is observed a relative stabilization in PET and m-LDPE reactors with SSV concentration around $550 \mathrm{mg} \mathrm{L}^{-1}$, however the SSV in HDPE reactors go on growing to arise $782 \mathrm{mg} \mathrm{L}^{-1}$. In phase 3 of experimentation it is noticed that HDPE experimented a further growing to $1000 \mathrm{mg} \mathrm{L}^{-1}$; meanwhile, with $\mathrm{m}$-LDPE, the SSV concentration remains constant in around $550 \mathrm{mg} \mathrm{L}^{-1}$, while PET reactors experimented a little but constant growing in SSV values from $612 \mathrm{mg} \mathrm{L}^{-1}$ to $660 \mathrm{mg} \mathrm{L}^{-1}$.

Regarding to SSV attached to the materials. The quantity of biomass was measured by the amount of SSV by area. This trend is directly correlated with the surface morphology, which is higher in m-LDPE than the other materials assessed. The decreasing roughness is presented as follow: $\mathrm{m}$-LDPE $>$ PET $>$ HDPE, this trend corresponds with the amount of SSV found, which were $2.09 \mathrm{~g} \mathrm{~L}^{-1}, 1.02$ $\mathrm{g} \mathrm{L}^{-1}$ and $0.25 \mathrm{~g} \mathrm{~L}^{-1}$ to $\mathrm{m}$-LDPE, PET and HDPE respectively. This fact is probably done by the influence of roughness in the adhesion. The attachment will occurs most readily in rougher, hydrophobic and coated by surface-conditioning films [23]. Moreover, this phenomena has been demonstrated by several authors [24,25]two moving-bed biofilm reactors (MBBR1 and MBBR2, who found a direct relationship between the cell adhesion with the surface properties. On the other hand, the materials evaluated, particularly the m-LDPE could be compared with other materials as polypropylene, which could attach $1.35 \mathrm{~g} \mathrm{~m}^{-2}$ of SSV [20].

According to morphology surface observations done by SEM in Figure 3.a and 3.b, it is possible to observe the differences in the surface between LDPE with and without thermal treatment; after the modification, a micro roughness was achieved in m-LDPE (3.b), it favors the growth and development of biofilm observed in 3.c. This finding is corroborated by Ammar and Oh $[13,14]$, who noted a better biofilm adherence in roughness surface than smooth surfaces. Also, the observations in the other materials 3(d) and 3(f) PET and HDPE respectively without biofilm, and 3(e) and 3(g) with biofilm, show that there is not too much biofilm formation. The SEM images indicate that the biofilm adhesion depends on the roughness of the materials, as roughness is high, more biofilm adhesion is produced. Many factors are involved in the adherence mechanism, including electrostatic forces, contact angle, and contact area. Besides, Jadjiev [26], evaluate fibrous materials suitable for the packing of the aerobic fixed bed reactor (AFBR), especially because the material provides a high specific surface for microbial fixation, high porosity and relatively low pressure drop. In the present research, the biomass fixation follows the same trend, it is to say that the microbial attachment was improved as long as the material is more roughness.

Biomass is directly correlated with SSV concentration in the mixed liquor $[15,19,20]$; the findings showed in Figure 4 demonstrate that m-LDPE and PET are more stable in terms of SSV release, meanwhile HDPE showed less stability, it is mainly because the low surface roughness, which do not let to attach the biomass stronger. It happened particularly when the organic loading increase, to this study, the equilibrium was achieved to organic loading of 2.4 to $3.5 \mathrm{~kg} \mathrm{COD} \mathrm{m}^{-3} \mathrm{~d}^{-1}$ to m-LDPE and PET, however the HDPE could not maintain attached the biomass to these applied loadings.

\section{Organic Matter Removal}

The COD concentration and its removal efficienty during the three assessed phases is showed in the figure 5.a) and 5.b).

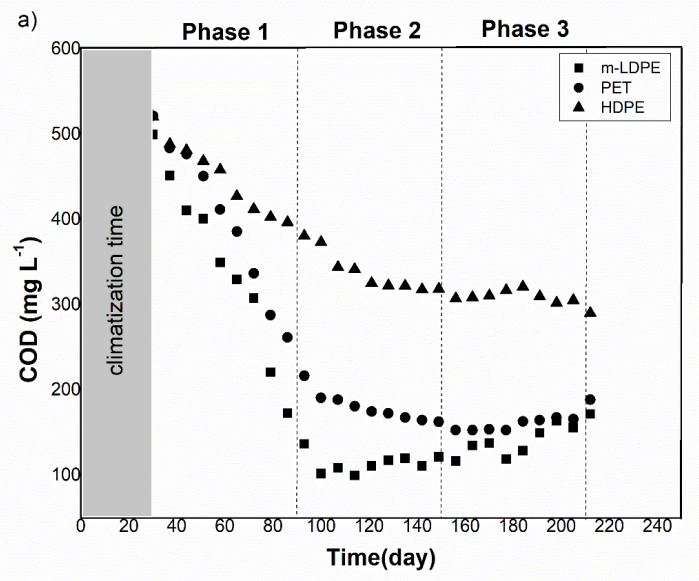




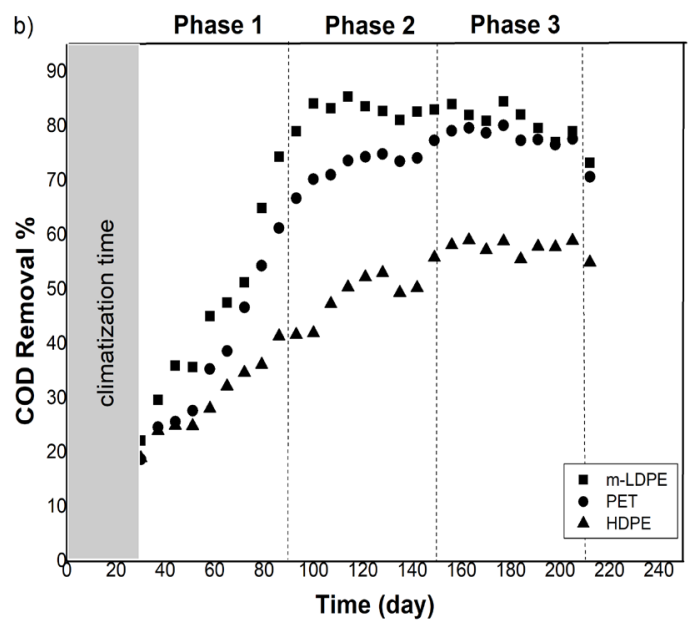

Figure 5. COD removal along the experimentation conditions; a) COD concentration vs. time; b) Efficiency of COD removal vs. time

In figure 5.a) it is noticed that during the phase 1 all reactors experimented a decrease; to HDPE the COD effluent concentration from $518.93 \mathrm{mg} \mathrm{L}^{-1}$ to $383.53 \mathrm{mg}$ $\mathrm{L}^{-1}$. Meanwhile, in the case of m-LDPE and PET the COD concentration decrease similarly from $519 \mathrm{mg} \mathrm{L}^{-1}$ to 200 $\mathrm{mg} \mathrm{L}^{-1}$ around. During the phase 2 and 3 all of them remain constant but in different levels; HDPE in around $300 \mathrm{mg}$ $\mathrm{L}^{-1}$, while PET in approximately $170 \mathrm{mg} \mathrm{L}^{-1}, \mathrm{~m}$-LDPE also experimented a stabilization in low values of around 110 $\mathrm{mg} \mathrm{L}^{-1}$.

The figure 5.b) shows the efficiency of the reactors versus time. Throughout the phase 1 the COD removal increase from $30 \%$ to up to $42 \%$ for HPDE, and reach $65 \%$ and $74 \%$ for PET and $\mathrm{m}$-LDPE respectively. It was analyzed that the m-LDPE and PET materials achieved higher efficiency in the reactors during the phase 2 and 3, with maximum values around $85.5 \%$ and $80.46 \%$ respectively.

The COD removal in Figure 5.a) showed the minimum COD concentration achieved using the plastic materials, the equilibrium presented in phase 2 and 3 for PET and $\mathrm{m}$-LDPE is mainly because these materials retain better the organic matter, in accord to the material characterization done by SEM. The amount of fixed biomass is directly proportional to the organic matter removal. In the experiments done by Aygun [25] (C) 2013 Balaban Desalination Publications. All rights reserved.Abstract: The operational performance of the sequencing batch reactor (SBR, showed that in SBR reactors handling the $60 \%$ of volume occupied by kaldnes support materials, they obtained $94.2 \%$ of COD elimination. The use of marine shell to treat of wastewater from artisanal mills gives $84.4 \%$ removal efficiency with organic volumetric load of $3.7-5.1$ $\mathrm{kg} \mathrm{COD} \mathrm{m-}{ }^{3}$ and $26 \mathrm{~h}$ of hydraulic retention time [27], were obtained, and demonstrated that one of the explanatory reasons for the good results are greater specific area, density and chemical composition being important characteristics in the development of the microorganism.

In the study of aerobic reactors with fixed support medium using PET bottles [21] ha sido utilizado en muchas partes del mundo con diferentes sistemas de depuración de contaminantes. Sin em -bargo se ha comprobado que muchos de estos contaminantes representan un peligro para la salud del hombre y seres vivos. Debido a lo anterior el objetivo de esta investigación fue implementar un reactor biológico rec-tangular de 90 litros de capacidad, aireado y conteniendo en su interior botellas plásticas de pet (polietileno tereftalato, the materials was proved be efficient in the removal of COD in wastewater with a similar value of $80 \%$ than in the present research. In the case of some recyclable plastic materials in the treatment of wastewater [30], these authors determined that the polymer PUR and Icopor (Polyester PS) obtained better performance in the removal of organic load from the $80 \%$, using gravel as a target in biological treatment.

Bassin [24]two moving-bed biofilm reactors (MBBR1 and MBBR2, stipulate that the use of conventional support materials in biofilm reactors in moving bed, with

organic load from 0.8 to $3.2 \mathrm{~kg}$ COD m$^{-3} \mathrm{~d}^{-1}$, increased the concentration of biomass in the carrier material. According to Hadjiev [26], they analyzed new results of fibrous materials which could be suitable for the packing of the aerobic fixed bed reactor (AFBR), especially since they provide a high specific surface for microbial fixation.

\section{Conclusions}

The three-support media evaluated PET, HDPE and $\mathrm{m}$-LDPE contributed for the development and growth of biofilm. However, the technical feasibility is limited at the use of PET and m-LDPE. The materials m-LDPE and PET evaluated in the reactors, achieved high removal of organic matter, and better biofilm adhesion in the support material compared with HDPE, which can be concluded that these polymers are effective for use as carrier materials at the operational conditions applied (1.6 to $3.5 \mathrm{~kg} \mathrm{COD} \mathrm{m}^{-3}$ $\mathrm{d}^{-1}$ ). The reactors with HDPE plastic waste, obtained the lowest organic matter removal, due to its smooth surface, where the biomass did not stay fixed and therefore tends to detach, and increase the amount of sludge, gradually decreasing the efficiency of the bioreactor. Thus, HDPE plastic is not advisable as a support in this kind of system. 


\section{Agradecimientos}

Este trabajo fue financiado por la Universidad Técnica de Machala, mediante proyecto de investigación aprobado por el H.C.U. № 294/2017.

\section{References}

[1] Ministerio de Agricultura Ganadería Acuacultura y Pesca: "La política agropecuaria ecuatoriana". Quito, (2016).

[2] Shyue K. and Schonfeld P. M.: "Multiple period optimization of bus transit systems". Transp. Res. Part B Vol. 25 (6) (1991) 453-478.

[3] Ruiz M.; Tobalina C., Demey-Cedeño H., BarronZambrano J. A. and Sastre A. M.: "Sorption of boron on calcium alginate gel beads". React. Funct. Polym. Vol. 73 (4) (2013) 653-657.

[4] Rinaudo M.: "Biomaterials based on a natural polysaccharide: alginate". Rev. Espec. en Ciencias Químico-Biológicas Vol. 17 (1) (2014) 92-96.

[5] Lapo B., Demey H., Zapata J., Romero C. and Sastre A. M.: "Sorption of $\mathrm{Hg}$ (II) and $\mathrm{Pb}$ (II) ions on chitosaniron (iii) from aqueous solutions: single and binary systems". Polymers (Basel). Vol. 10 (367) (2018).

[6] Demey H., Lapo B., Ruiz M., Fortuny A., Marchand M. and Sastre A.: "Neodymium recovery by chitosan/ iron(iii) hydroxide [chifer(iii)] sorbent material: batch and column systems". Polymers (Basel). Vol. 10 (2) (2018) 204.

[7] Boltz J. P., Morgenroth E., Brockmann D., Daigger G. T., Henze M., Rittmann B., Sorense K., Takacs I., Vanrolleghem P. A. and Loosdrecht M. van.: "Framework for biofilm reactor model calibration". In WWTmod 2012, (2010), pp 2-5.

[8] Lewandowski Z.: "Biofilms in water and wastewater treatment". (2011).

[9] Van Loosdrecht M. C. M., Eikelboom D., Gjaltema A., Mulder A., Tijhuis L. and Heijnen J.: "Biofilm structures". Water Sci. Technol. Vol. 32 (8) (1995) 35-43.

[10] Nicolella C., Van Loosdrecht M. C. M. and Heijnen J. J.: "Wastewater treatment with particulate biofilm reactors". J. Biotechnol. Vol. 80 (1) (2000) 1-33.

[11] Hallab N. J., Bundy K. J., O'Connor K., Moses R. L. and
Jacobs J. J.: "Evaluation of metallic and polymeric biomaterial surface energy and surface roughness characteristics for directed cell adhesion". Tissue Eng. Vol. 7 (1) (2001) 55-71.

[12] Kwok W. K., Picioreanu C., Ong S. L., Van Loosdrecht M. C. M., Ng W. J. and Heijnen J. J.: "Influence of biomass production and detachment forces on biofilm structures in a biofilm airlift suspension reactor". Biotechnol. Bioeng. Vol. 58 (4) (1998) 400407.

[13] Oh Y. J., Lee N. R., Jo W., Jung W. K. and Lim J. S.: "Effects of substrates on biofilm formation observed by atomic force microscopy". Ultramicroscopy Vol. 109 (8) (2009) 874-880.

[14] Ammar Y., Swailes D., Bridgens B. and Chen J.: "Influence of surface roughness on the initial formation of biofilm". Surf. Coatings Technol. Vol. 284 (2015) 410-416.

[15] Nava Urrego L. M., Gasperín Sanchéz R. y Durán Moreno A.: «Comparación de un reactor de biomasa suspendida y un reactor de biomasa adherida para la biodegradación de compuestos tóxicos presentes en aguas residuales de refinerías de petróleo». Rev. Int. Contam. Ambient. Vol. 30 (1) (2014) 101-112.

[16] American Public Health Association, American Water Works Association and Water Environment Federation.: "Standard methods for the examination of water and wastewater", 21st ed., American Public Health Association, (2005).

[17] Tchobanoglous G., Burton F. L. and Stensel H. D.: "wastewater engineering: treatment and reuse", Cuarta Edición, New Delh, India, (2003).

[18] Hach Company: "Manual de Análisis de Agua", Loveland, (2000).

[19] Chu L. and Wang J.: "Comparison of polyurethane foam and biodegradable polymer as carriers in moving bed biofilm reactor for treating wastewater with a low C/N ratio". Chemosphere Vol. 83 (1) (2011) 63-68.

[20] Lapo B., Romero H., Martínez O., García C. and Lemus M.: "CODs removal of domestic wastewater by solid plastic wastes materials: influence of organic loading rate". Int. J. Appl. Environ. Sci. Vol. 13 (7) (2018) 595-604.

[21] Alomía P. and Paspuel M.: «Creación de una empresa 
de compañía limitada de acopio y comercialización de desechos de cartón, papel, plástico y vidrio en la ciudad de ibarra, provincia de Imbabura», Universidad Técnica del Norte, (2011).

[22] Pol E.: «factores involucrados en el manejo de la basura doméstica por parte del ciudadano», Universidad de Barcelona, (2003).

[23] Costa F., Silva B.and Tavares T.: "Biofilm bioprocesses", Current developments in Biotechnology and Bioengineering. (2017) 143-175

[24] Bassin J. P., Dias I. N., Cao S. M. S., Senra E., Laranjeira Y. and Dezotti M.: "Effect of increasing organic loading rates on the performance of moving-bed biofilm reactors filled with different support media: assessing the activity of suspended and attached biomass fractions". Process Saf. Environ. Prot. Vol. 100 (2016) 131-141.

[25] Aygun A., Nas B., Berktay A., Ates H.: "Application of sequencing batch biofilm reactor for treatment of sewage wastewater treatment: effect of power failure". Desalin. Water Treat. Vol. 52 (37-39) (2014) 37-41.
[26] Hadjiev D., Dimitrov D., Martinov M., Sire O.: "Enhancement of the biofilm formation on polymeric supports by surface conditioning". Enzyme Microb. Technol. Vol. 40 (4) (2007) 840-848.

[27] Cárdenas Calvachi G. L., Ramos Ramos R. M.: «evaluación de la eficiencia de reactores de lecho fijo utilizando aguas mieles residuales de trapiches artesanales». Cienc. e Ing. Neogranadina Vol. 19 (1) (2009) 25-38.

[28] Lapo B., Muñoz M., Romero H., Pozo M. J., Ayala H.: «PET Y PP usado como medios de crecimiento be biopelícula fija aplicada al tratamiento aerobio de aguas residuales domésticas». In $\mathbf{X X}$ Congresso Brasileiro de Engenharia Química, (2015), pp 65226530.

[29] Mendoza M., Rodríguez J.: «Reactor aerobio como medio de soporte fijo utilizando botellas PET». Vol. 12 (2016).

[30] Cervera J., Tavera J.: «Evaluación de algunos materiales plásticos reciclables como medios filtrantes para aguas residuales». (2007) 76-82. 


\section{REVISTA TECNICA}

DE LA FACULTAD DE INGENIERIA

UNIVERSIDAD DEL ZULIA

Vol. 42. N², Mayo-Agosto 2019, pp. 47 - 97

Esta revista fue editada en formato digital y publicada en Abril de 2019, por el Fondo Editorial Serbiluz, Universidad del Zulia. Maracaibo-Venezuela

www.luz.edu.ve

www.serbi.luz.edu.ve

produccioncientifica.Iuz.edu.ve 